\title{
Herbicides selectivity in pre-budded seedlings of sugarcane
}

\section{Seletividade de herbicidas em mudas pré-brotadas de cana-de-açúcar}

\author{
José Luiz Carvalho de Souza Dias' ${ }^{1}$, Antonio Carlos da Silva Junior ${ }^{1 *}$, \\ Juliana Roberta Gobi Queiroz ${ }^{2}$, Dagoberto Martins ${ }^{1}$
}

\begin{abstract}
Herbicides are expected to show selectivity towards cultivated plants, i.e., they ought to control weeds without jeopardizing the development and productivity of crops. The objective of this project was to evaluate the selectivity of herbicides applied in pre-planting of three sugar cane cultivars which were planted according to the system of pre-budded seedlings (PBS) under climatic natural conditions, between September and November of 2013. The experiment was set according to a completely random design with four replications. The treatments were distributed according to a factorial scheme of $3 \times 8$, in which factor A was the cultivar (CTC14, CTC7, and RB966928), and factor B was the herbicide (in g.ha ${ }^{-1}$ ): S-metolachlor $(2,640)$, clomazone $(1,000)$, sulfentrazone $(800)$, diclosulam (200), metribuzin $(1,920)$, diuron + hexazione $(1,170+330)$, S-metolachlor + sulfentrazone $(2,640+800)$, and a no treatment. The visual symptoms of intoxication were evaluated $14,28,35,42,49,56$, and 63 days after application (DAA), the height and number of tillers 14, 35, 49, 56, and 63 DAA, the dry weight of shoot (DWS), and the dry weight of root (DWR) 63 DAA. Under the conditions of the experiment, the herbicides $S$-metolachlor, clomazone, metribuzin, diuron + hexazinone, and S-metolachlor + sulfentrazone were selective towards the presprouted sugar-cane plantlets. Diclosulam was the less selective herbicide, followed by sulfentrazone. Cultivar CTC14 was visually the less tolerant to the herbicides diclosulam and sulfentrazone.
\end{abstract}

KEYWORDS: chemical control; phytointoxication; Saccharum spp.; pre-planting.
RESUMO: Os herbicidas devem apresentar seletividade às culturas agrícolas, ou seja, controlar as plantas daninhas sem comprometer o desenvolvimento nem a produtividade da cultura. O objetivo deste trabalho foi avaliar a seletividade de herbicidas aplicados em pré-plantio de três cultivares de cana-de-açúcar plantados pelo sistema de mudas pré-brotadas (MPB). O experimento foi desenvolvido na Usina São Martinho, próximo ao município de Pradópolis (SP), sob condições naturais de clima, no período de setembro a novembro de 2013. O delineamento experimental utilizado foi o inteiramente casualizado, com quatro repetiçóes. Os tratamentos foram distribuídos em esquema fatorial $(3 \times 8)$, sendo o fator A composto de três cultivares: CTC14, CTC7 e RB966928; e o fator B por sete herbicidas (em g.ha $\left.{ }^{-1}\right)$ : S-metolachlor (2,640); clomazone (1,000); sulfentrazone (800); diclosulam (200); metribuzin $(1,920)$; diuron + hexazinone $(1,170+330)$; S-metolachlor + sulfentrazone $(2,640+$ 800); mais uma testemunha sem aplicação de herbicidas. Foram avaliados os sintomas visuais de fitointoxicação aos 14, 28, 35, 42, 49, 56 e 63 dias após aplicação (DAA), a altura e o número de perfilhos dos cultivares aos 14, 35, 49 e 63 DAA, a massa seca da parte aérea (DWS) e a massa seca do sistema radicular (MSSR) aos 63 DAA. Nas condiçôes em que o experimento foi conduzido, os herbicidas S-metolachlor, clomazone, metribuzin, diuron + hexazinone e $S$-metolachlor + sulfentrazone foram seletivos às mudas pré-brotadas de cana-de-açúcar. O herbicida diclosulam foi o menos seletivo, seguido do sulfentrazone. O cultivar CTC14 apresentou-se visualmente menos tolerante aos herbicidas diclosulam e sulfentrazone.

PALAVRAS-CHAVE: controle químico; fitointoxicação; Saccharum spp.; pré-plantio. 


\section{INTRODUCTION}

Planting sugar cane by the pre-budded seedlings (PBS) shows several advantages such as the reduction of the volume of plantlets needed for the planting, crops of better quality and vigor, as well as the reduction of the risks of diffusion of diseases and insects vectors. In addition to that, it speeds up the introduction of new varieties in the area (LANDELL et al., 2012).

Independently of the chosen planting system, controlling weeds is of very high importance. According to VICTORIA FILHO; CHRISTOFFOLETI (2004), one of the most important problems of the sugar-cane crop is the interference caused by weeds, which may cause crop losses of the order of $85 \%$. There are different weed control methods with the chemical one being the most widely used due to its efficacy and low cost (CHRISTOFFOLETI et al., 2006). Among the herbicides used in sugar cane crops, the residual ones applied in pre-emergence of the weeds and the crop are the ones most frequently used.

For the chemical control of weeds, herbicides selectivity is the basis of success, and the recommendation of a herbicide is conditioned to its selectivity, i.e., to its capacity of eliminating undesirable plant species without causing significant economical reductions both in the product quality as well as to its quantity (VELINI et al., 2000). Positioning the preemergence herbicide properly in the soil is the main factor of its selectivity (OLIVEIRA JR.; INOUE, 2011).

The application of herbicides at the planting with presprouted plantlets may be done pre or post emergence of the weed plants and pre (with or without incorporation) or post planting of the pre-sprouted plantlets. When the application of the herbicides is done in pre-emergence of the weeds and before the planting of the pre-budded seedlings, the plantlets roots are located in the herbicide treated zone, differently from the conventional plantings in which the roots are located below the treated zone. This fact may lead to the loss of selectivity and thus to significant damage.

So, the objective of this project was to evaluate the selectivity of herbicides applied in pre-emergence in three sugar cane cultivars with planting being done by using PBS.

\section{MATERIAL AND METHODS}

The experiment was carried out in the São Martinho sugar and alcohol factory, in the municipality of Pradópolis, a county in the state of São Paulo, Brazil, under natural climatic conditions, from September to November of 2013, and whose geographical location is of $21^{\circ} 21^{\prime} 34^{\prime \prime} \mathrm{S}$ and $48^{\circ} 03^{\prime} 56^{\prime \prime} \mathrm{WGr}$; the mean altitude of the area is of $538 \mathrm{~m}$ above sea level. Polyethylene vases with a 12-liter capacity were used. Soil from the upper soil layer from a Red Yellow latosol (EMBRAPA, 2006) was also used. The soil physical and chemical composition was $28 \%$ sand, $7 \%$ silt and $65 \%$ clay; $\mathrm{pH}$ in $\mathrm{CaCl}_{2}=5.5 ; \mathrm{P}($ resin $)=$ $53 \mathrm{mg} \cdot \mathrm{dm}^{-3} ; \mathrm{K}=3.0 \mathrm{mmol} \cdot \mathrm{dm}^{-3} ; \mathrm{Ca}=37 \mathrm{mmol} \cdot \mathrm{dm}^{3} ; \mathrm{Mg}=$ $15 \mathrm{mmol}_{c} \cdot \mathrm{dm}^{3} ; \mathrm{H}+\mathrm{Al}=29 \mathrm{mmol}_{c} \cdot \mathrm{dm}^{3} ; \mathrm{CTC}=84.0 \mathrm{mmol}_{\mathrm{c}}$; $\mathrm{V} \%=66$ and formula $8-28-16$. The results of the chemical analysis showed that the soil needed no liming.

The herbicides were applied before the planting of PBS on September $14^{\text {th }} 2013$. Planting took place soon after the herbicides were applied. On the planting day, the PBS were approximately $15 \mathrm{~cm}$ long and bearing from three to five leaves. The herbicides were sprayed with the help of a $\mathrm{CO}_{2}$ pressurized costal sprayer with two nozzles, Teejet XR 11002VS, spaced by $50 \mathrm{~cm}$ and under a constant pressure of $200 \mathrm{kPa}$, presenting a volume of $200 \mathrm{~L}^{\mathrm{L}} \mathrm{ha}^{-1}$. At the moment of the application, the temperature was between 28 and $30.1^{\circ} \mathrm{C}$, the relative humidity of the air was between 65 and $57.9 \%$, wind speed between 5.1 and $6.5 \mathrm{~km} \cdot \mathrm{h}^{-1}$ and nebulosity was between 30 and $25 \%$, at the beginning and the end of the application, respectively.

The experiment was set according to a completely random design with four replications. The treatments were distributed according to a factorial scheme $(3 \times 8)$, in which the A factor was represented by the cultivars (CTC14, CTC7, and RB966928) and B, the seven herbicides: S-metolachlor $\left(2,640 \mathrm{~g} \cdot \mathrm{ha}^{-1}\right)$, clomazone $\left(1,000 \mathrm{~g} \cdot \mathrm{ha}^{-1}\right)$, sulfentrazone $(800 \mathrm{~g}$. ha $\left.^{-1}\right)$, diclosulam (200 g.ha $\left.{ }^{-1}\right)$, sulfentrazone (800 g.ha $\left.{ }^{-1}\right)$, metribuzin $\left(1,920 \mathrm{~g} \cdot \mathrm{ha}^{-1}\right)$, diuron + hexazinone $(1,170+$ $\left.330 \mathrm{~g} \cdot \mathrm{ha}^{-1}\right)$, S-metolachlor + sulfentrazone $(2,640+800 \mathrm{~g}$. $\mathrm{ha}^{-1}$ ), and no treatment (no herbicide applied). The chosen cultivars were, at the time of the experiment, largely used by sugar cane growers (CTC, 2014; RIDESA, 2014), because they displayed different tolerances to herbicides. CTC7, RB966928, and CTC14 are considered tolerant, intermediate and susceptible to the herbicides, respectively. The chosen herbicides were those most widely used by farmers and of different physico-chemical characteristics.

The analyzed characteristics were visual symptoms of intoxication by means of a scale of percentage in which zero corresponds to no injury and 100 corresponds to the death of the plant (SBCPD, 1995). The observations were made $14,28,35,42,49,56$, and 63 days after application (DAA). Plant height and number of tillers were determined 14, 35, 49 , and 63 DAA, the dry weight of shoot (DWS) and the dry weight of root (DWR) at 63 DAA.

The results were submitted to the analysis of variance by F-test, and the means were compared by the Tukey test $(5 \%)$. The statistical program used was Sisvar 5.0.

\section{RESULTS AND DISCUSSION}

The herbicides had a significant effect on the visual symptoms of intoxication since 14 DAA. In general, the most 
agressive treatments were, in decreasing order, diclosulam, sulfentrazone, and the association between S-metolachlor and sulfentrazone. Diclosulam resulted in the clearest symptoms of intoxication during the period between 35 and 49 DAA (Table 1). The most important symptoms were a lighter green color in the leaves and a reduction of height and vigor of the plants. These results are in disagreement with those ones reported by TERRA (2003) and MARTINS et al. (2005), in whose works no symptom was detected in sugar cane plantlets treated with diclosulam applied in pre-emergence.

Sulfentrazone was the second most toxic herbicide. The period in which the symptoms were more clearly visible was that between 21 and $42 \mathrm{DAA}$, though the toxicity symptoms of sulfentrazone started to dissipate 49 DAA and were almost completely gone 63 DAA (Table 1). The main intoxication symptom was the presence of purple spots followed by necrosis in the leaves. Under pre-emergence conditions, BARELA (2005) and NEGRISOLI (2002) observed no intoxication symptoms caused by sulfentrazone, thus in disagreement with our results.

The association of S-metolachlor and sulfentrazone was the third most toxic treatment. Probably, the intoxication symptoms of that mixture were less severe than those of isolated sulfentrazone due to a possible antagonic effect between those products, considering that the sulfentrazone doses were the same in both treatments (Table 1).

S-metolachlor, clomazone, metribuzin and diuron + hexazinone were visually selective to the PBS, since they caused intoxication symptoms lower than $2.1 \%$ during the whole experimental period (Table 1). Making use of clomazone in pre-emergence, NEGRISOLI et al. (2002), BARELA (2005) and SANDANIEL et al. (2008) also reported selectivity of sugar cane to this herbicide. BARELA (2005) also observed no intoxication signs caused by diuron + hexazinone applied in pre-emergence to sugar cane.

Cultivar effects on the visual symptoms of intoxication evaluated 42, 56, and 63 DAA were significant. At those three moments, CTC14 was the most affected one, followed by RB966928. CTC7 was the less affected one (Table 1).

Observations made 14, 28, 56, and 63 DAA showed a statistically significant interaction between herbicides and cultivars (Table 1).

In Table 2, one may observe the mean values resulting from the partitioning of the sum of squares of the degrees of freedom of the treatments, when the interactions were significant.

Table 1. Percent mean values of intoxication caused by different herbicides applied in pre-planting to three sugar cane cultivars. Pradópolis, state of São Paulo, Brazil, 2013.

\begin{tabular}{|c|c|c|c|c|c|c|c|c|c|}
\hline \multirow{2}{*}{ Treatments } & \multirow{2}{*}{ Rate $\left(g . h a^{-1}\right)$} & \multicolumn{8}{|c|}{ Days after application } \\
\hline & & 14 & 21 & 28 & 35 & 42 & 49 & 56 & 63 \\
\hline \multicolumn{10}{|l|}{ Herbicide Effect (H) } \\
\hline S-met ${ }^{1}$ & 2,640 & $1.5 c$ & $1.3 c$ & $1.1 \mathrm{c}$ & $1.4 \mathrm{c}$ & $0.9 \mathrm{~d}$ & $0.2 \mathrm{~d}$ & $0.2 c$ & $0.3 c$ \\
\hline clomazone & 1.000 & $1.6 c$ & $1.0 c$ & $0.7 c$ & $0.0 c$ & $0.3 d$ & O.Od & O.Oc & O.Oc \\
\hline sulfe ${ }^{2}$ & 800 & $4.6 b$ & $25.8 a$ & $25.5 a$ & $25.7 a$ & $22.7 b$ & $12.2 \mathrm{~b}$ & $8.0 b$ & $5.6 b$ \\
\hline diclosulam & 200 & $8.3 a$ & $16.8 b$ & $21.9 a$ & $29.8 a$ & $34.6 a$ & $31.4 a$ & $27.3 a$ & $26.3 a$ \\
\hline metribuzin & 1,920 & $2.1 \mathrm{bc}$ & $1.9 c$ & $1.8 c$ & $1.8 \mathrm{c}$ & $1.3 d$ & $0.4 d$ & $0.2 c$ & $0.0 c$ \\
\hline diuron + hexa ${ }^{3}$ & $1,170+330$ & $0.9 c$ & $0.9 c$ & $0.7 c$ & $0.5 c$ & $0.3 d$ & $0.0 d$ & $0.0 c$ & $0.0 c$ \\
\hline S-met ${ }^{1}+$ sulfe $^{2}$ & $2,640+800$ & $1.4 \mathrm{c}$ & $15.8 b$ & $16.5 b$ & $16.2 b$ & $15.3 c$ & $7.3 c$ & $5.3 b$ & $3.0 b c$ \\
\hline \multicolumn{10}{|l|}{ Cultivars Effect (C) } \\
\hline СТC 14 & & - & - & - & - & $12.6 a$ & - & $7.8 a$ & $6.4 \mathrm{~A}$ \\
\hline СТC7 & & - & - & - & - & $9.9 a b$ & - & $4.6 b$ & 4.1B \\
\hline RB966928 & & - & - & - & - & $9.8 b$ & - & $5.1 b$ & $4.5 a b$ \\
\hline F Herbicides $(\mathrm{H})$ & & $17.9^{* *}$ & $110.0^{* *}$ & $165.4^{* *}$ & $160.6^{* *}$ & $125.7^{* *}$ & $107.2^{* *}$ & $95.4^{* *}$ & $109.6^{* *}$ \\
\hline F Cultivars (C) & & $1.0^{\text {ns }}$ & $0.5^{\text {ns }}$ & $1.0^{\text {ns }}$ & $2.0^{\text {ns }}$ & $3.9^{*}$ & $1.9^{\text {ns }}$ & $6.6^{*}$ & $4.3^{*}$ \\
\hline$F(H \times C)$ & & $1.9^{*}$ & $1.3^{\mathrm{ns}}$ & $4.5^{\star *}$ & $1.4^{\mathrm{ns}}$ & $1.9^{\text {ns }}$ & $0.9^{\text {ns }}$ & $2.5^{*}$ & $2.7^{*}$ \\
\hline C.V. (\%) & & 74.4 & 37.3 & 30.8 & 32.8 & 39.5 & 52.9 & 60.5 & 63.4 \\
\hline $\operatorname{LSD}(H)$ & & 2.7 & 4.2 & 3.7 & 4.4 & 5.3 & 4.8 & 4.4 & 3.9 \\
\hline $\operatorname{LSD}(C)$ & & 1.4 & 2.1 & 1.9 & 2.3 & 2.7 & 2.5 & 2.3 & 2.0 \\
\hline
\end{tabular}

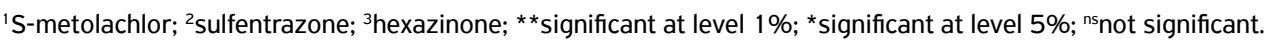

Means followed by the same letter on the column do not significantly between the different treatment by Tukey test $(p>0,05)$. 
On the $14^{\text {th }}$ DAA, the only herbicide showing different responses of the cultivars was diclosulam. Among the cultivars, CTC14 and RB966928 were the ones most severely injured by the herbicides. On the $28^{\text {th }}$ DAA, cultivars CTC14 and RB966928 showed the highest sensitivity to diclosulam, whereas to sulfentrazone the most sensitive ones were cultivars CTC14 and CTC7. Observations made 56 DAA showed that only diclosulam caused significant injury to the cultivars, with the exception of CTC14 - in this cultivar, sulfentrazone also caused injury, although less severe than those caused by diclosulam. At the end of the study, on the $63^{\text {rd }}$ DAA, the only herbicide different from the others was the diclosulam - it caused high levels of intoxication in the three cultivars with CTC14, being the most severely injured one (Table 2).

The results of the analysis of variance of the data concerning plant height and the effects of the herbicides and cultivars are shown in Table 3.
The herbicides had a significant influence on plant height since 14 DAA (Table 3). Fourteen DAA, herbicides had caused significant differences in the height of the plantlets, although none of them differed statistically from the no-treatment case. From 28 DAA onwards up to the last observation, only diclosulam caused reductions in plant height. These data are in agreement with those of visual intoxication symptoms caused by diclosulam (Table 1).

S-metolachlor, clomazone, sulfentrazone, metribuzin, diuron + hexazinone, and S-metolachlor + sulfentrazone did not cause reductions in PBS height in all evaluation periods, and are, thus, considered to be selective as to this aspect.

Taking into consideration pre-emergence applications, DINARDO-MIRANDA et al. (2001) verified plant height reduction in sugar cane treated with metribuzin $(1,680 \mathrm{~g}$. $\left.\mathrm{ha}^{-1}\right)$ and clomazone (1,000 g.ha- $\left.{ }^{-1}\right)$. These results are supposed to be associated to doses, soil texture and the planting system.

Table 2. Percent mean values of intoxication in the interaction between three sugar cane cultivars and different herbicides applied in pre-planting. Pradópolis, state of São Paulo, Brazil, 2013.

\begin{tabular}{|c|c|c|c|c|c|c|c|}
\hline \multirow{2}{*}{ Treatments } & \multirow{2}{*}{$\begin{array}{c}\text { Rate } \\
\left(\mathrm{g} \mathrm{ha}^{-1}\right)\end{array}$} & \multicolumn{3}{|c|}{$14 \mathrm{DAA}^{3}$} & \multicolumn{3}{|c|}{$28 \mathrm{DAA}^{3}$} \\
\hline & & СТС 14 & CTC7 & RB966928 & СТС 14 & CTC7 & RB966928 \\
\hline S-meto ${ }^{1}$ & 2,640 & $1.3 \mathrm{~b} \mathrm{~A}$ & 1.8ab A & $1.5 b c A$ & $1.0 \mathrm{c} A$ & $0.5 \mathrm{c} \mathrm{A}$ & $1.8 \mathrm{~b} \mathrm{~A}$ \\
\hline clomazone & 1,000 & $1.5 \mathrm{~b} \mathrm{~A}$ & 2.3ab A & $1.0 b c \mathrm{~A}$ & $0.5 c \mathrm{~A}$ & $1.5 \mathrm{cA}$ & $0.0 b \mathrm{~A}$ \\
\hline sulfent ${ }^{2}$ & 800 & 4.0ab A & 5.0a A & $4.8 \mathrm{~b} \mathrm{~A}$ & $30.0 \mathrm{a} A$ & $26.5 a \mathrm{~A}$ & 20.0a B \\
\hline diclosulam & 200 & 8.5a A & 4.8ab B & $11.5 \mathrm{a} A$ & 26.0a A & $16.5 b \mathrm{~B}$ & 23.3a A \\
\hline metribuzin & 1,920 & $2.3 \mathrm{~b} \mathrm{~A}$ & $1.5 a b \mathrm{~A}$ & $2.5 b c A$ & $2.0 \mathrm{c} \mathrm{A}$ & $1.8 \mathrm{c} \mathrm{A}$ & $1.8 \mathrm{~b} \mathrm{~A}$ \\
\hline diuron + hexazinone & $1,170+330$ & $1.3 \mathrm{~b} \mathrm{~A}$ & $0.3 b \mathrm{~A}$ & $1.3 b c A$ & $0.8 \mathrm{c} \mathrm{A}$ & $0.8 \mathrm{cA}$ & $0.5 b \mathrm{~A}$ \\
\hline S-meto ${ }^{1}+$ sulfent $^{2}$ & $2,640+800$ & $2.8 \mathrm{~b} \mathrm{~A}$ & $1.5 a b \mathrm{~A}$ & O.Oc A & $12.5 \mathrm{~b} \mathrm{~B}$ & $18.8 \mathrm{~b} \mathrm{~A}$ & 18.3a A \\
\hline $\operatorname{LSD}^{4}(H)$ & & & 4.7 & & & 6.5 & \\
\hline $\operatorname{LSD}(\mathrm{V})$ & & & 3.7 & & & 5.1 & \\
\hline \multirow{2}{*}{ Treatments } & \multirow{2}{*}{$\begin{array}{c}\text { Rate } \\
\left(g_{\left.h a^{-1}\right)}\right.\end{array}$} & \multicolumn{3}{|c|}{$56 \mathrm{DAA}^{3}$} & \multicolumn{3}{|c|}{$63 \mathrm{DAA}^{3}$} \\
\hline & & СТС 14 & CTC7 & RB966928 & СТС 14 & CTC7 & RB966928 \\
\hline S-meto ${ }^{1}$ & 2,640 & O.Oc A & $0.5 \mathrm{~b} \mathrm{~A}$ & $0.0 b \mathrm{~A}$ & O.Oc A & $0.8 \mathrm{~b} \mathrm{~A}$ & O.Ob A \\
\hline clomazone & 1,000 & O.Oc A & O.Ob A & O.Ob A & O.Oc A & O.Ob A & O.Ob A \\
\hline sulfent $^{2}$ & 800 & $13.5 b \mathrm{~A}$ & $5.3 \mathrm{~b} \mathrm{~B}$ & $5.3 b \mathrm{~B}$ & $9.0 b \mathrm{~A}$ & 4.3bAB & $3.5 \mathrm{~b} \mathrm{~B}$ \\
\hline diclosulam & 200 & $34.8 \mathrm{a} A$ & $22.3 a$ B & 25.0a B & $33.5 a \mathrm{~A}$ & $21.0 a \mathrm{~B}$ & 24.3a B \\
\hline metribuzin & 1,920 & O.Oc A & $0.5 b \mathrm{~A}$ & $0.0 b \mathrm{~A}$ & O.Oc A & $0.0 b \mathrm{~A}$ & O.Ob A \\
\hline diuron + hexazinone & $1,170+330$ & O.Oc A & $0.0 b \mathrm{~A}$ & $0.0 \mathrm{~b} \mathrm{~A}$ & O.Oc A & O.Ob A & $0.0 \mathrm{~b} A$ \\
\hline S-meto ${ }^{1}+$ sulfent $^{2}$ & $2,640+800$ & $6.5 b c A$ & 4.Ob A & $5.5 b \mathrm{~A}$ & $2.5 \mathrm{bcA}$ & $2.5 \mathrm{~b} \mathrm{~A}$ & $4.0 \mathrm{~b} \mathrm{~A}$ \\
\hline $\operatorname{LSD}^{4}(H)$ & & \multicolumn{3}{|c|}{7.6} & \multicolumn{3}{|c|}{6.8} \\
\hline LSD (V) & & \multicolumn{3}{|c|}{6.0} & \multicolumn{3}{|c|}{5.4} \\
\hline
\end{tabular}

${ }^{1}$ S-metolachlor; ${ }^{2}$ sulfentrazone; ${ }^{3}$ days after application, ${ }^{4}$ least significant difference.

Means followed by the same lowercase letters, in the columns, within each cultivar and uppercase, in the lines between the cultivars in each period, do not significantly between the different treatment and cultivars by Tukey test $(p>0,05)$. 
Significant cultivar effects on plantlet height were verified from observations starting 14 DAA (Table 3). In general, CTC7 showed the highest means in all evaluated periods. Cultivars CTC14 and RB966928 did not differ significantly. The highest plant height values in CTC7 could be explained by the cultivar intrinsic characteristics, since its being an erect plant makes it easier to have a higher adaptability to mechanical sowing and harvesting (CTC, 2014).

Herbicide $v$ s. cultivar interaction had no significant effect on plantlet height (Table 3).

The results of the analysis of variance of data regarding the number of tillers and the effects of herbicides and cultivars are shown in Table 4.

Herbicides had a significant effect on the reduction of number of tillers, as shown by observations made 28,42 , and 56 DAA. The only treatment causing reduction in the number of tillers was diclosulam, with a mean lower than two tillers up to 56 DAA (Table 4).

MARTINS et al. (2005) reported to have found no reduction in tiller number when diclosulam was applied in preemergence. These results do no support the ones presented here, probably because the planting system of pre-sprouted plantlets was not used.
Taking in consideration pre-emergence applications, DINARDO-MIRANDA et al. (2001) verified, in sugar cane, that the application of metribuzin $\left(1,680 \mathrm{~kg} \cdot \mathrm{ha}^{-1}\right)$, clomazone (100 g.ha $\left.{ }^{-1}\right)$, and clomazone + (diuron + hexazinone) $\left(1,000+468+132\right.$ g.ha $\left.{ }^{-1}\right)$ caused significant reduction in tiller number, i.e., conflicting results with the ones herein reported. These conflicting results may be ascribed to the planting system and soil texture, since DINARDOMIRANDA et al. (2001) used similar doses to the ones used in this study in a sandy soil.

All the other treatments with S-metolachlor, clomazone, sulfentrazone, metribuzin, and diuron + hexazinone were selective as to the number of tillers of pre-sprouted plantlets from 14 to 56 DAA, which all showed significant difference only from the treatment with diclosulam.

Cultivar effects on number of tillers were significant in the observations made 28,42 , and 56 DAA (Table 4). The largest number of tillers in cultivar RB966928 may be related to intrinsic characteristics of the cultivar since it is classified as a high-tillering cultivar (RIDESA, 2014).

The interactions of the effects of the herbicides and those of the cultivars on the number of tillers were significant at the $28^{\text {th }}$ and the $42^{\text {nd }}$ DAA (Table 4). Table 5 shows the mean

Table 3. Mean values of height $(\mathrm{cm})$ caused by different herbicides applied in pre-planting to three sugar cane cultivars. Pradópolis, state of São Paulo, Brazil, 2013.

\begin{tabular}{|c|c|c|c|c|c|}
\hline \multirow{2}{*}{ Treatments } & \multirow{2}{*}{ Rate (g ha-1) } & \multicolumn{4}{|c|}{ Days after application } \\
\hline & & 14 & 28 & 42 & 56 \\
\hline \multicolumn{6}{|l|}{ Herbicide Effect $(\mathrm{H})$} \\
\hline S-meto ${ }^{1}$ & 2,640 & $8.02 a b$ & $10.67 a$ & $11.41 \mathrm{a}$ & $15.66 a$ \\
\hline clomazone & 1,000 & $8.75 a$ & $12.25 a$ & $13.48 a$ & $18.63 a$ \\
\hline sulfe ${ }^{2}$ & 800 & $7.71 \mathrm{ab}$ & $11.09 a$ & $11.73 a$ & $16.56 a$ \\
\hline diclosulam & 200 & $6.54 b$ & $7.96 b$ & $8.77 b$ & $11.10 b$ \\
\hline metribuzin & 1,920 & 7.24ab & $10.78 a$ & $12.30 a$ & $16.18 a$ \\
\hline diuron + hexaz ${ }^{3}$ & $1,170+330$ & $6.96 a b$ & $11.35 a$ & $12.58 a$ & $17.39 a$ \\
\hline S-meto ${ }^{1}+$ sulfe $^{2}$ & $2,640+800$ & 7.17ab & $10.89 a$ & $11.82 a$ & $16.27 a$ \\
\hline No treatment & - & $8.28 a b$ & $11.86 a$ & $13.30 a$ & $17.82 a$ \\
\hline \multicolumn{6}{|l|}{ Cultivars Effect (C) } \\
\hline СТС 14 & & $7.02 b$ & $10.27 b$ & $11.22 b$ & $14.92 b$ \\
\hline СТС7 & & $9.48 a$ & $13.24 a$ & $14.33 a$ & $19.98 a$ \\
\hline RB966928 & & $6.25 b$ & $9.03 c$ & $10.21 b$ & $14.20 b$ \\
\hline F Herbicides $(\mathrm{H})$ & & $2.38^{*}$ & $7.76^{* *}$ & $9.12^{* *}$ & $10.36^{* *}$ \\
\hline F Cultivars (C) & & 33.24 ** & $57.85^{* *}$ & 51.72 ** & 43.52 ** \\
\hline$F(H \times C)$ & & $0.87^{\mathrm{ns}}$ & $0.96^{\mathrm{ns}}$ & $0.80^{\text {ns }}$ & $0.94^{\mathrm{ns}}$ \\
\hline C.V. (\%) & & 21.86 & 14.81 & 14.17 & 15.15 \\
\hline $\operatorname{LSD}(H)$ & & 2.11 & 2.05 & 2.15 & 3.13 \\
\hline LSD (C) & & 0.99 & 0.96 & 1.01 & 1.47 \\
\hline
\end{tabular}

'S-metolachlor; ${ }^{2}$ sulfentrazone; ${ }^{3}$ hexazinone; ${ }^{*}$ significant at level $1 \%$; *significant at level $5 \%$; ${ }^{\text {ns }}$ not significant.

Means followed by the same letter on the column do not significantly between the different treatment by Tukey test $(p>0.05)$. 
values of the partitioning of the sum of squares of the degrees of freedom of the treatments in those periods.

On the $28^{\text {th }} \mathrm{DAA}$, the treatments with clomazone, diclosulam, and diuron + hexazinone led to a significant reduction in tiller number in cultivar CTC14, in comparison to the treatment with sulfentrazone. However, none of the treatments differed significantly from the no treatment case. In cultivar CTC7, the treatment with metribuzin resulted in a significantly higher number of tillers than that of the diclosulam. None of the treatments differed significantly from the no treatment case, though. Diclosulam caused a significant reduction in the number of tillers of cultivar RB966928.

On the $42^{\text {nd }} \mathrm{DAA}$, it was verified that clomazone, diclosulam, and metribuzin resulted in cultivar CTC14 significant reductions in comparison with no treatment case. In cultivar CTC7, diclosulam did not lead to significant differences in comparison with the treatment with diuron + hexazinone and no treatment group, but, when compared to the other herbicides, its negative effects were significant. For cultivar RB966928, data from the $28^{\text {th }}$ DAA showed that diclosulam caused a significant reduction in the number of tillers in comparison with other herbicides.
In general, it was observed that the intoxication caused by the herbicides to the plantlets (Table 5) led to a reduction in the number of tillers since the herbicide causing the strongest symptoms of intoxication (diclosulam) was also the one causing the largest reduction in the number of tillers.

The results of the analysis of variance reffering to the accumulated DWR and DWS and the effects of herbicides and cultivars are shown in Table 6.

Herbicides had a significant effect on the accumulation of DWR and DWS, as measured on the $63^{\text {rd }}$ DAA (Table 6). The treatment with diclosulam, followed by the treatment with sulfentrazone, caused significant reductions in DWR, but only the treatment with diclosulam caused significant reductions in the accumulation of DWS. On the other hand, the plantlets treated with diclosulam showed an accumulation of dry matter in the root system much lower than that observed for treatment with sulfentrazone.

The effects of cultivars were significant for the accumulation of DWS when measured on the $63^{\text {rd }} \mathrm{DAA}$, but not for the accumulation of DWR (Table 6). The highest amount of accumulated DWS was observed for cultivar CTC14 and the lowest one for RB966928. No difference in comparison with the others was observed in cultivar CTC7.

Table 4. Mean values of number of tillers caused by different herbicides applied in pre-planting to three sugar cane cultivars. Pradópolis, state of São Paulo, Brazil, 2013.

\begin{tabular}{|c|c|c|c|c|c|}
\hline \multirow{2}{*}{ Tratments } & \multirow{2}{*}{ Rate $\left(g \mathrm{ha}^{-1}\right)$} & \multicolumn{4}{|c|}{ Days after application } \\
\hline & & 14 & 28 & 42 & 56 \\
\hline \multicolumn{6}{|l|}{ Herbicide Effect $(\mathrm{H})$} \\
\hline S-metolachlor & 2,640 & - & $3.6 a$ & $4.3 a$ & $5.7 a$ \\
\hline clomazone & 1,000 & - & $3.3 a$ & $4.2 \mathrm{a}$ & $4.9 a$ \\
\hline sulfentrazone & 800 & - & $3.8 a$ & $4.8 \mathrm{a}$ & $6.3 a$ \\
\hline diclosulam & 200 & - & $1.3 b$ & $1.3 b$ & $1.2 b$ \\
\hline metribuzin & 1,920 & - & $3.8 a$ & $4.3 a$ & $5.2 \mathrm{a}$ \\
\hline diuron + hexazinone & $1,170+330$ & - & $2.8 a$ & $4.3 a$ & $5.3 a$ \\
\hline S-metolachlor + sulfentrazone & $2,640+800$ & - & $3.1 \mathrm{a}$ & $4.3 a$ & $5.3 a$ \\
\hline No treatment & - & - & $3.5 a$ & $4.6 a$ & $5.3 a$ \\
\hline \multicolumn{6}{|l|}{ Cultivars Effect (C) } \\
\hline СTC 14 & & - & $2.6 b$ & $3.5 b$ & $5.1 \mathrm{ab}$ \\
\hline CTC7 & & - & $2.8 b$ & $3.5 b$ & $4.2 b$ \\
\hline RB966928 & & - & $4.0 a$ & $5.0 a$ & $5.4 a$ \\
\hline F Herbicides $(\mathrm{H})$ & & $1.6^{\mathrm{ns}}$ & $6.4^{* *}$ & $9.8^{* *}$ & 11.9 ** \\
\hline F Cultivars (C) & & $1.9^{\text {ns }}$ & $13.3^{* *}$ & 15.9 ** & $5.7^{*}$ \\
\hline $\mathrm{F}(\mathrm{H} \times \mathrm{C})$ & & $1.3^{\mathrm{ns}}$ & $2.0^{*}$ & $2.3^{*}$ & $1.2^{\mathrm{ns}}$ \\
\hline C.V. (\%) & & 45.4 & 36.5 & 30.5 & 32.1 \\
\hline $\operatorname{LSD}(\mathrm{H})$ & & 0.7 & 1.5 & 1.6 & 2.0 \\
\hline $\operatorname{LSD}(C)$ & & 0.3 & 0.7 & 0.8 & 0.9 \\
\hline
\end{tabular}

** Significant at level 1\%; *significant at level 5\%; ${ }^{\text {ns}}$ not significant.

Means followed by the same letter on the column do not significantly between the different treatment by Tukey test $(p>0,05)$. 
The accumulation of DWR and DWS by the presprouted plantlets was not significantly influenced by the interaction between the herbicides and cultivars (Table 6).
In general, it was observed that the intoxication brought about by the treatments with the herbicides (Table 5) resulted in lower production of DWS and mainly of DWR. GALON et al. (2009), in a study of herbicide selectivity in sugar cane,

Table 5. Mean values of the number of tillers in the interaction between three sugar cane cultivars and different herbicides applied in pre-planting. Pradópolis, state of São Paulo, Brazil, 2013.

\begin{tabular}{|c|c|c|c|c|c|c|c|}
\hline \multirow{2}{*}{ Treatmnets } & \multirow{2}{*}{ Rate (g.ha-1) } & \multicolumn{3}{|c|}{$28 \mathrm{DAA}^{4}$} & \multicolumn{3}{|c|}{$42 \mathrm{DAA}^{4}$} \\
\hline & & СТС 14 & CTC7 & RB966928 & СТС 14 & СТC7 & RB966928 \\
\hline S-meto ${ }^{1}$ & 2,640 & 2.8ab A & 3.5ab A & $4.5 a \mathrm{~A}$ & 3.8ab A & 4.5a A & 4.8a A \\
\hline clomazone & 1,000 & $1.5 b \mathrm{~B}$ & 3.5ab A & 5.0a A & $2.5 b \mathrm{~B}$ & $4.5 a \mathrm{~A}$ & 5.5a A \\
\hline sulfe $^{2}$ & 800 & 4.3a A & 3.0ab A & 4.0a A & 4.3ab A & 4.3a A & 6.0a A \\
\hline diclosulam & 200 & $1.5 \mathrm{~b} \mathrm{~A}$ & $1.0 b \mathrm{~A}$ & $1.3 \mathrm{~b} \mathrm{~A}$ & $1.8 \mathrm{~b} \mathrm{~A}$ & $1.0 b \mathrm{~A}$ & $1.3 \mathrm{~b} \mathrm{~A}$ \\
\hline metribuzin & 1,920 & 3.0ab A & 4.0a A & 4.3a A & 3.Ob B & 4.3a A & 5.8a A \\
\hline diuron + hexa $^{3}$ & $1,170+330$ & $1.5 \mathrm{~b} \mathrm{~B}$ & 2.0ab B & 4.8a A & 3.8ab B & 3.Oab B & 6.3a A \\
\hline S-meto ${ }^{1}+$ sulfe $^{2}$ & $2,640+800$ & 3.0ab A & 2.3ab A & 4.0a A & 3.5ab B & 3.8a A & 5.8a A \\
\hline No treatment & - & 3.5ab A & 3.0ab A & 4.0a A & 5.8a A & 3.Oab B & 5.0a A \\
\hline $\operatorname{LSD}(\mathrm{H})$ & & & 2.5 & & & 2.7 & \\
\hline $\operatorname{LSD}(C)$ & & & 1.9 & & & 2.1 & \\
\hline
\end{tabular}

${ }^{1}$ S-metolachlor; ${ }^{2}$ sulfentrazone; ${ }^{3}$ hexazinone; ${ }^{4}$ days after application.

Means followed by the same lowercase letters, in the columns, within each cultivar and uppercase, in the lines between the cultivars in each period, do not significantly between the different treatment and cultivars by Tukey test $(p>0.05)$.

Table 6. Mean values of the dry weight shoot and dry weight root on the $63^{\text {rd }}$ DAA in pre-planting of different herbicides in three sugar cane cultivars. Pradópolis, state of São Paulo, Brazil, 2013.

\begin{tabular}{|c|c|c|c|}
\hline \multirow{2}{*}{ Treatments } & \multirow{2}{*}{ Rate $\left(g \cdot h a^{-1}\right)$} & \multicolumn{2}{|c|}{ Dry weight (g) } \\
\hline & & Root & Shoot \\
\hline \multicolumn{4}{|l|}{ Herbicide Effect $(\mathrm{H})$} \\
\hline S-metolachlor & 2,640 & $6.45 a b$ & $9.82 a$ \\
\hline clomazone & 1,000 & $6.51 \mathrm{ab}$ & $10.21 \mathrm{a}$ \\
\hline sulfentrazone & 800 & $5.28 b$ & $10.03 a$ \\
\hline diclosulam & 200 & $1.81 \mathrm{c}$ & $3.02 b$ \\
\hline metribuzin & 1,920 & $5.67 a b$ & $10.02 a$ \\
\hline diuron + hexazinone & $1,170+330$ & $6.77 a b$ & $9.04 a$ \\
\hline S-metolachlor + sulfentrazone & $2,640+800$ & $7.20 a b$ & $9.93 a$ \\
\hline No treatment & - & $7.54 a$ & $9.19 a$ \\
\hline \multicolumn{4}{|l|}{ Cultivars Effect (C) } \\
\hline CTC14 & & - & $10.29 a$ \\
\hline CTC7 & & - & $9.15 a b$ \\
\hline RB966928 & & - & $7.20 b$ \\
\hline F Herbicides $(\mathrm{H})$ & & $16.00^{* *}$ & 5.47 ** \\
\hline F Cultivars (C) & & $2.16^{\mathrm{ns}}$ & $5.75^{*}$ \\
\hline $\mathrm{F}(\mathrm{H} \times \mathrm{C})$ & & $1.36^{\mathrm{ns}}$ & $0.91^{\mathrm{ns}}$ \\
\hline C.V. (\%) & & 26.55 & 40.15 \\
\hline $\operatorname{LSD}(\mathrm{H})$ & & 0.93 & 4.56 \\
\hline LSD (C) & & 1.99 & 2.14 \\
\hline
\end{tabular}

** Significant at level $1 \%$; *significant at level $5 \%$; ${ }^{\text {ns }}$ not significant.

Means followed by the same letter on the column do not significantly between the different treatment by Tukey test $(p>0.05)$. 
also observed that the most intense symptoms of intoxication were related to the lowest DWS values.

It is worthwhile to mention that most of the mentioned studies which showed that the evaluated treatments showed selectivity were conducted in conventional plantings. The planting of pre-sprouted plantlets has some particularities which may cause damage to the crop.

The first particularity in the management of herbicides when planting PBS is the abscence of selectivity by positioning or toponomic selectivity. In the conventional method of planting sugar cane, the positioning selectivity was verified to occur since the planting material is positioned at a depth between 25 and $30 \mathrm{~cm}$, far from the zone where the herbicides are placed $(3$ to $5 \mathrm{~cm}$ ). When the herbicides are applied before planting the PBS, at planting, the plantlets will be placed right on top of the treated surface rather than below it. In addition to that, the PBS already show a large number of roots when they reach the field. These roots are the main via by which residual herbicides are absorbed.

Crop age is another factor intensifying herbicide effects in the PBS. Young plants have less specialized tissues, thus increasing the translocation of herbicides inside the plants (OLIVEIRA JR.; INOUE, 2011).

The physico-chemical characteristics of the soil, which interact with herbicides and thus influence their adsorption, are the organic matter content, the texture and mineralogy, the cation exchanging capacity, $\mathrm{pH}$ and the water content. The soil used in this experiment shows high levels of those characteristics, therefore contributing for a larger adsorption of the herbicides molecules. Thus, these herbicides may lead to different results from the ones of this experiment.

The physico-chemical characteristics of the herbicides which influence their adsorption, and thus their selectivity by the crop, are: water solubility (S), coefficient of the herbicide distribution in the soil and the organic matter $\left(\mathrm{K}_{\mathrm{d}}, \mathrm{K}_{\mathrm{oc}}\right)$; coefficient of the octanol-water $\left(\mathrm{K}_{\mathrm{ow}}\right)$ partition; and the electrolitic dissociation capacity $(\mathrm{pK})$. According to OLIVEIRA JR; INOUE (2011), for herbicides whose $\mathrm{pK}$ is equal to zero (non-ionizable), the Kow, Koc, and $S$ are the most impactant characteristics on the adsorption of herbicide molecules. In addition to that, they have more affinity with the organic fraction than with the mineral fraction of the soil. The non-ionizable herbicides used in this experiment were S-metolachlor, clomazone, and diuron + hexazinone, whose Kow and Koc values (with the exception of hexazinone) favor a larger sorption of the herbicide, leading to a lower availability of the herbicide in the soil solution and thus reducing the chances of their being absorbed by the pre-sprouted plantlets. For those herbicides whose pk value is larger than zero (ionizables), in addition to Kow, Koc and S, the $\mathrm{pK}$ and $\mathrm{pH}$ values of the soil, also have a very strong influence on the sorption of herbicide molecules. These ionizable herbicides have a higher affinity with the mineral fraction than with the organic fraction of the soil. The ionizable herbicides used in this experiment were diclosulam, sulfentrazone, and metribuzin. All of them had low Koc values and, in a $\mathrm{pH}$ in $\mathrm{CaCl}_{2}=5.5$, they are lowly adsorbed and have, thus, their availability increased in the soil solution, which increases their chances of being absorbed in large quantities.

It is supposed that the diclosulam (the most toxic herbicide in the experiment) and sulfentrazone (the second most toxic herbicide) herbicides are not properly metabolized by those cultivars. Specifically in the case of diclosulam, other factors may have intensified its effects on the cultivars, such as its efficient translocation inside the plant (translocation via xylem/phloem) and also not having to go long distances inside the plant to reach its action site.

Considering all high effect factors on selectivity, it is possible to conclude that the treatments with S-metolachlor, clomazone, and diuron + hexazinone were selective mainly due to their physico-chemical characteristics, which favor a greater adsorption to the soil colloids, and thus, with decreasing chances of being absorbed in large quantities and/or to factors linked to the plant (differentiated absorption, differentiated translocation and metabolization). On the other hand, in treatments with metribuzin, selectivity was probably influenced by factors related to the plant, since its physicochemical characteristics favor a larger availability in the soil solution and thus increases its chances of being absorbed in large quantities.

It is necessary to remember that this study produced important results concerning the selectivity of herbicides in pre-sprouted plantlets of three sugar cane cultivars. But, since it was conducted in vases, it is necessary to conduct it again, in the field, with the evaluation of production and technological parameters, to confirm the results herein presented.

\section{CONCLUSION}

Under the conditions prevailing during this experiment, the data allowed the conclusion that the diclosulam herbicide was less selective to the sugar cane cultivars planted with PBS, followed by sulfentrazone. The S-metolachlor, clomazone, metribuzin, diuron + hexazinone and S-metolachlor + sulfentrazone herbicides were selective to the sugar cane cultivars planted with PBS. Visually, cultivar CTC14 was the least tolerant one to diclosulam and sulfentrazone in comparison with cultivars RB966928 and CTC7. 

REFERENCES

BARELA, J.F. Seletividade de herbicidas para a cultura da cana-deaçúcar (Saccharum spp.) afetada pela interação com nematicidas aplicados no plantio. 2005. 83f. Dissertação (Mestrado em Agronomia) - Escola Superior de Agricultura "Luiz de Queiroz", Universidade de São Paulo, Piracicaba, 2005.

CHRISTOFFOLETI, P.J.; BORGES, A.; NICOLAI, M.; CARVALHO, S.P.J.; LÓPEZ-OVEJERO, R.F.; MONQUERO, P.A. Carfentrazoneethyl aplicado em pós-emergência para o controle de Ipomoea spp. e Commelina benghalensis na cultura da canade-açúcar. Planta Daninha, Campinas, v.24, n.1, p.8390, 2006. Disponível em: <http://dx.doi.org/10.1590/ SO100-83582006000100011>.

CTC. Centro de Tecnologia Canavieira. Variedades CTC. Disponível em: <http://www.ctcanavieira.com.br/downloads/ variedades2013WEB3.pdf > . Acesso em: 10 ago. 2014.

DINARDO-MIRANDA, L.L.; GARCIA, V.; JACON, J.J. Efeito da Interação entre nematicidas e herbicidas em cana-de-açúcar. Nematologia brasileira, v.25, n.2, p.197-203, 2001.

EMBRAPA. Empresa Brasileira de Pesquisa Agropecuária. Centro Nacional de Pesquisa Agropecuária de Solos. Sistema brasileiro de classificação de solos. Rio de Janeiro, 2006. 412p.

GALON, L.; FERREIRA, E.A.; FERREIRA, F.A.; SILVA, A.A.; BARBOSA, M.H.P.; REIS, M.R.; SILVA, A.F.; CONCENÇO, G.; ASPIAZÚ, I.; FRANÇA, A.C.; TIRONE, S.P. Influência de herbicidas na qualidade da matéria-prima de genótipos de cana-de-açúcar. Planta Daninha, Viçosa-MG, v.27, n.3, p.555-562, 2009.

LANDELL, M.G.A.; CAMPANA, M.P.; FIGUEIREDO, P.; XAVIER, M.A.; ANJOS, I.A.; DINARDO-MIRANDO, L.L.; SCARPARI, M.S.; GARCIA, J.C.; BIDÓIA, M.A.P.; SILVA, D.N.; MENDONÇA, J.R.; KANTHACK, R.A.D.; CAMPOS, M.F.; BRANCALIÃO, S.R.; PETRI, R.H.; MIGUEL, P.E.M. Sistema de multiplicação de canade-açúcar com uso de mudas pré-brotadas (MPB), oriundas de gemas individualizadas. Campinas: IAC, 2012. (Documentos, 109). Disponível.em: <http://www.iac.sp.gov.br/publicacoes/ porassunto/pdf/Doc\%20109_online.pdf >. Acesso em: 20 jun. 2014.
MARTINS, D.; VELINI, E.D.; NEGLISOLE, E.; MARCHI, S.R.; SILVA, J.R.V. Seletividade do diclosulam aplicado em pré-emergência e pós-emergência em diversas cultivares de cana-de-açúcar. Revista Brasileira de Herbicidas, Passo Fundo, v.4, n.2, p.77-85, 2005.

NEGRISOLI, E. Seletividade de herbicidas aplicados em préemergência e associados a nematicidas, à cultura da cana-deaçúcar, cultivar RB8551 13. 2002. 48f. Dissertação (Mestrado em Agricultura) - Faculdade de Ciências Agronômicas, Universidade Estadual Paulista “Júlio de Mesquita Filho”, Botucatu, 2002.

OLIVEIRA JR., R.S; INOUE, M.H. Seletividade de herbicidas para culturas e plantas daninhas. In: Biologia e Manejo de Plantas Daninhas. Curitiba: Omnipax, 348p., cap.10, 2011.

RIDESA. Rede Interuniversitária para o Desenvolvimento do Setor Sucroalcooleiro. Catálogo nacional de variedades "RB" de cana-de-açúcar. 2010. Disponível em: <http://canaufv.com. br/catalogo/catalogo-2010.pdf>. Acesso em: 08 ago. 2014.

SANDANIEL, C.R.; FERNANDEZ, L.B.; BARROSO, A.L.L. Controle de plantas daninhas em cana soca com herbicidas aplicados em pré-emergência. Núcleos, Ituverava, n. 1, p.1-10, 2008.

SOCIEDADE BRASILEIRA DA CIÊNCIA DAS PLANTAS DANINHAS. SBCPD. Procedimentos para instalação, avaliação e análise de experimentos com herbicidas. Londrina, 1995. 42p.

TERRA, M.A. Seletividade de diclosulam, trifloxysulfuron-sodium e ametryne a cultivares de cana-de-açúcar. 2003. 60 f. Dissertação (Mestrado em Agricultura) - Faculdade de Ciências Agronômicas, Universidade Estadual Paulista “Júlio de Mesquita Filho”, Botucatu, 2003.

VELINI, E.D.; MARTINS, D.; MANOEL, L.A.; MATSUOKA, S.; TRAVAIN, J.C.; CARVALHO, J.C. Avaliação da seletividade da mistura de oxyfluorfen e ametryne, aplicada em pré ou pós-emergência, a dez cultivares de cana-de-açúcar (cana-planta). Planta Daninha, Viçosa, v.18, n.1, p.123-134, 2000.

VICTÓRIA FILHO, R.; CHRISTOFFOLETI, P.J. Manejo de plantas daninhas e produtividade da cana. Visão Agrícola, Piracicaba, n. 1, p.32-37, 2004. 